\title{
Use of the Blue Ocean Strategy to obtain ports 4.0
}

INGENIERÍA CIVIL

\section{Empleo de la Estrategia del Océano Azul para obtener}

\section{puertos 4.0}

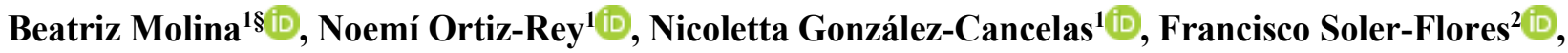 \\ Alberto Camarero-Orive ${ }^{1}(\mathbb{D}$ \\ ${ }^{I}$ Universidad Politécnica de Madrid, Departamento de Ingeniería Civil, Transporte y Territorio, \\ Escuela Técnica Superior de Ingenieros de Caminos, Canales y Puertos, Madrid, España \\ ${ }^{2}$ Universidad Carlos III de Madrid, Departamento de Informática, Madrid, España \\ §beatriz.molinas@alumnos.upm.es,noemiortizrey@gmail.com,nicoleta.gcancelas@upm.es,fsoler@inf.uc3m.es, \\ alberto.camarero@upm.es
}

Recibido: 13 de abril de 2020 - Aceptado: 07 de septiembre de 2020

\begin{abstract}
The fourth industrial revolution is characterized by a high level of digitalization of systems and processes. This revolution has reached the Spanish ports. They have been investing for years in the implementation of new technologies, aimed at promoting sustainability and environmental quality, as well as seeking a more efficient and orderly logistics. Ports are moving towards their digital transformation, which is materialized in the well-known Ports 4.0. These intelligent ports, or Smart Ports, cover a multitude of aspects and variables. Automation, digitalization, technologies that allow interoperability, transparency, decentralization, and customer experience define the context of the application of the concept 'Ports 4.0' to the Spanish logistics-port sector. How to achieve a satisfactory digitization process that allows progress towards Port 4.0 in the Spanish port system is one of the questions being raised recently. The Spanish port world could be represented by a red ocean, since in a very generalist way it can be said that it is a marked described by a fierce competition lacking in differentiation. Therefore, with this proposal, the aim is to take the Spanish port system to a blue ocean, where a suitable strategy and innovation generate leaps in value that make competitors irrelevant because customers compare different products and services. To be able to respond to this, the Blue Ocean Strategy is planted, leaving aside the competition between ports and generating new demand. From the study carried out, it is concluded that Spanish ports still have a long way to go in terms of sustainability. It also concludes that a new management model would mean the innovation in value that is necessary for the process towards ports 4.0.
\end{abstract}

Keywords: Blue ocean strategy, Digitalization, Ports 4.0. 


\section{Resumen}

La cuarta revolución industrial se caracteriza por una alta digitalización de los sistemas y los procesos. Esta revolución ha llegado a los puertos españoles. Estos llevan años invirtiendo en la implantación de nuevas tecnologías dirigidas a impulsar la sostenibilidad y la calidad medioambiental, así como a buscar una logística más efíciente y ordenada. Los puertos avanzan imparablemente hacia su transformación digital, que se materializa en los conocidos Puertos 4.0. Estos puertos inteligentes o Smart Ports, abarcan multitud de aspectos y variables. Automatización, digitalización, tecnologías que permiten la interoperabilidad, transparencia, descentralización y experiencia del cliente definen el contexto de aplicación del concepto 'Puertos 4.0' al sector logístico-portuario español. Cómo alcanzar un proceso de digitalización satisfactorio que permita avanzar hacia puerto 4.0 en el sistema portuario español es una de las cuestiones que se están planteando en los últimos tiempos. El mundo portuario español podría representarse por un océano rojo, pues de forma muy generalista, se puede decir que está marcado por una feroz competencia carente de diferenciación. Por ello, con la propuesta lo que se pretende es llevar al sistema portuario español a un océano azul, donde una estrategia e innovación adecuada generan saltos de valor que hacen que los competidores sean irrelevantes porque los clientes comparan productos y servicios absolutamente diferentes. Para poder dar respuesta a ello se planta la Estrategia del Océano Azul, dejando de lado la competencia entre puertos y generando una nueva demanda. Del estudio desarrollado se concluye que los puertos españoles aún tienen un largo camino que recorrer en materia de sostenibilidad. Asimismo, se concluye que un nuevo modelo de gestión supondría la innovación en valor que necesaria en el proceso hacía puertos 4.0.

Palabras clave: Estrategia Océano azul, Digitalización, Puertos 4.0.

\section{Introduction}

Ports have played a fundamental role in international trade since their existence. However, their strategic position has changed considerably over the last twenty years, during which time there has been an evolution towards increasingly demanding operational and management standards. At the same time, the global scenario of port competitiveness has undergone significant changes. All the world's major ports have witnessed a transition in the focus of their economic development model, moving from a commitment to extensive growth to intensive growth ${ }^{(1)}$. The first of these placed emphases on increasing the workforce or its training, in addition to improvements in infrastructure and greater investment in capital and resources. On the other hand, intensive growth focuses on acquiring an innovative attitude, capable of progressing toward new ideas and values that drive improvements in the efficiency of the system, even if this means breaking with traditional schemes. This path towards the discovery of new and better methodologies allows improving the exploitation of the resources that can be used by a specific economy. Moreover, it opens a new path towards sustained development and improvement, and important qualitative leaps in welfare levels ${ }^{(2)}$.

The change in the vision of port operation allows progress to be made towards more transparent management models and to broaden the focus of interest towards other areas that favor port competitiveness beyond operational improvements (3). To facilitate this transformation, ports must make effective use of digital resources and strengthen their collaboration with industry, thus promoting added value in port activities ${ }^{(4)}$. Given the above, it can be said that the transformation of business models and innovation are two imperatives for ports around the world to take advantage of the opportunities offered by yet unknown markets ${ }^{(5)}$.

This process of improving the quality of port operations through technology has led to a progressive liberalization of the activities carried out in the ports of the Spanish State-owned Port System ${ }^{(6)}$. With the intention that these activities 
take place in respect of free competition and avoiding the formation of monopolies, the Port Authorities have been given the capacity to act on these issues. They are also responsible for promoting innovation and developing strategies to improve port competitiveness ${ }^{(7)}$.

Ultimately, traditional port services become the responsibility of the private sector, thus introducing greater flexibility in the provision of these services. As a result, the transmission of information in the port environment is also changing. Both physical and documentary flows converge in the logistics chains of ports, and technological advances allow for the streamlining of the processes of this information flow and thus improve the supply of services ${ }^{(8)}$.

Finally, the concepts of Smart Port and Port 4.0 appear because of this technological development and the new needs derived from its optimization. The keys to this new operation lie in the generalized application of digitalization and synchromodality to all processes, without forgetting other essential aspects such as security and sustainability. It can be said that digitalization is the main means for a 4.0 transformation in ports ${ }^{(9)}$. It is, therefore, necessary to establish a new groundbreaking scenario for synchromodality and digitization in the port sector, which this study aims to address through the Blue Ocean strategy.

Throughout history, seaports have been a source of wealth for the territories in which they are located, whether at the municipal, regional, or national level. Spread throughout the world, and given their importance for territorial economic development, they have evolved into a multitude of organizational and regulatory models (10). According to numerous studies on the evolution of the port sector, the globalization that the world market is currently undergoing in all its facets, with particular emphasis on the growth of international trade in goods, is leading to an increase in port competition (11). This phenomenon can be easily appreciated in the process of hierarchization and selection that is taking place in Spanish ports, where they are struggling to achieve a greater concentration of port traffic and the location of companies in their immediate surroundings, which also entails the agglutination of technological groups in a few coastal areas ${ }^{(12)}$.

In this context, two currents can be distinguished. One of them would be formed by those ports that stand out for this commercial development, struggling to offer a better service than the rest, and claiming to be the best solution for the customers' needs. These ports are active units with decision-making capacity due to their great power of influence. On the contrary, the second trend would be those ports with a more passive behavior, far from the general trend of globalization, and whose importance is only perceived at the local level ${ }^{(13)}$.

This contrast in behavior is evident in the different positions that the Port Authorities of the Spanish Port System have adopted concerning how the current Strategic Framework should evolve. To illustrate the current panorama, at the beginning of 2019 a study was carried out based on surveys that the Port Authorities had to complete to show their opinions regarding the various questions that were posed to them. These questions dealt with issues such as the governance of the system, planning and management, and the economic and financial regime ${ }^{(14)}$.

However, their strategic position has changed significantly over the last twenty years. According to numerous studies on the development of the port sector, the globalization which the world market is currently undergoing in all its facets, with the growth of international trade in goods being particularly relevant, is leading to an increase in port competition ${ }^{(15)}$. 
This phenomenon is easily appreciable in the process of hierarchization and selection that is taking place in Spanish ports, where they are struggling to achieve a greater concentration of port traffic and the location of companies in their closest surroundings, which also leads to the agglutination of technological groups in a few coastal areas ${ }^{(12)}$, while at the same time they are evolving towards increasingly demanding requirements in terms of operating and management standards. This path towards the discovery of new and better methodologies opens a new path towards sustained development and important qualitative leaps in the levels of well-being ${ }^{(1,2)}$.

This process of improving the quality of port operations through technology has led to a progressive liberalization of the activities carried out in the ports of the Spanish State-owned Port System ${ }^{(10)}$. With the intention that these activities take place in respect of free competition and avoiding the formation of monopolies, the Port Authorities have been given the capacity to act on these issues. Furthermore, they are responsible for promoting innovation and the development of strategies aimed at improving port competitiveness ${ }^{(16)}$. On the other hand, the concepts of Smart Port and Port 4.0 appear because of this technological development and the new needs derived from their optimization. The keys to this new operation lie in the generalized application of digitalization and synchromodality to all processes ${ }^{(17)}$, without forgetting other essential aspects such as security and sustainability.

The Blue Ocean strategy is a market strategy developed by W. Chan Kim and Renée Mauborgne ${ }^{(18)}$, professors at INSEAD (one of the most prestigious business schools in the world), which states that to achieve business success it is necessary to leave competition aside and look for a new demand, that is, to create blue oceans.

The first requirement, concerning competition, means that companies must stop competing to achieve success. Thus, all the companies that currently exist in the market are included in the red oceans, while the industries that are still unknown, those that do not exist at present, correspond to the blue oceans. The red oceans are so-called because "competition to the death stains the water of the red ocean with blood".

On the other hand, in the blue oceans, there is no competition, but rather new opportunities for profitability and growth. By not using competition as a benchmark against which to compare themselves, these oceans apply a different strategic logic, focused on obtaining value and on innovation, so-called value innovation. This takes place when differentiation and low cost are achieved at the same time. The principles used are non-competition and value innovation and tools used are a matrix of the four actors and value curve. Applying the Blue Ocean strategy to the Spanish port sector would be something new, as it has never been considered in this market. Moreover, given the scarcity of evidence of application of the strategy to the public sector, its application is a novelty not only at the level of the state port system, but also at the level of the Spanish public sector, and even worldwide.

\section{Methodology}

The steps that make up the methodology for developing the Blue Ocean strategy are those shown in Figure 1. These steps are aimed at characterizing the current market for the study industry and locating possible development alternatives that will differentiate it from the red oceans of that market. 


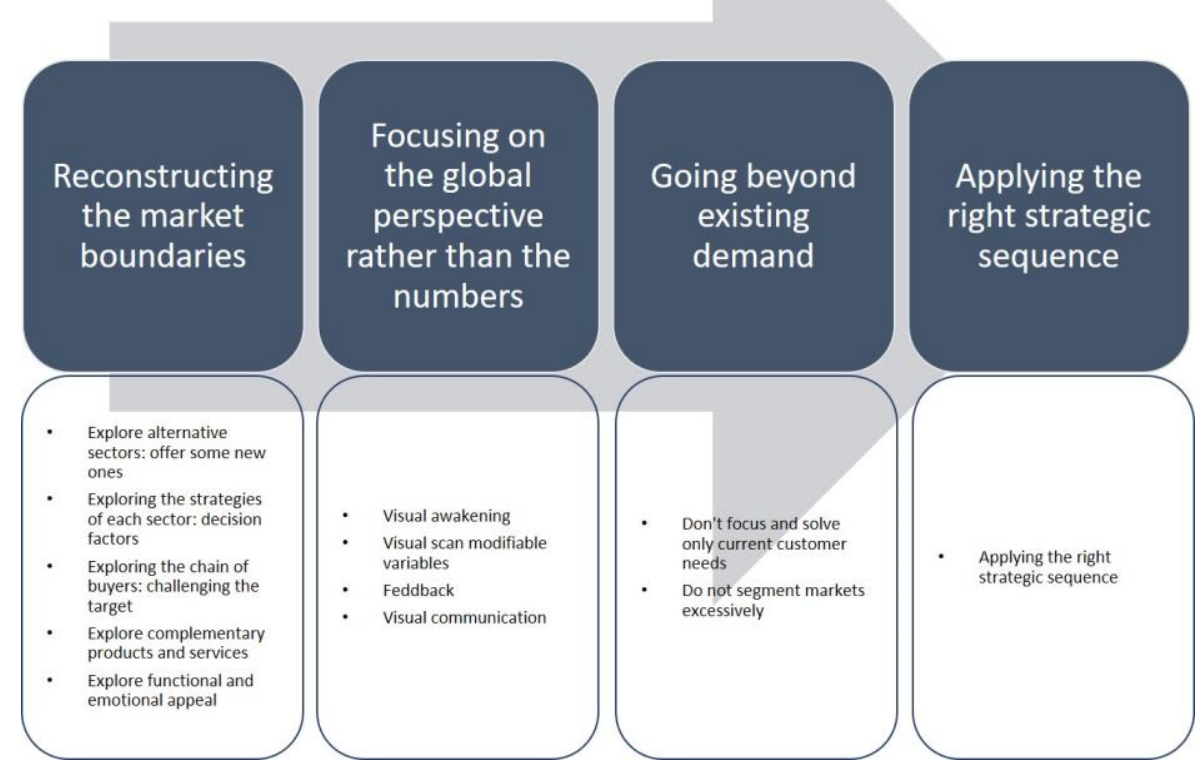

Figure 1. Methodological schedule

\subsection{Determination of the working scenario}

The determination of the work scenario will be done through diagnosis and analysis of the state of the art to identify the aspects that provide essential information for the development of the strategy.

\subsection{Blue Ocean Strategy}

The strategy to be developed is to follow the steps presented in Kim \& Mauborgne ${ }^{(18)}$.

\subsubsection{Reconstructing the market boundaries}

The principle of the Blue Ocean strategy that should be applied first is the reconstruction of market borders. To this end, among all the possibilities offered by the market, it is necessary to identify which of them all constitute commercially attractive opportunities for the creation of these oceans.

In Kim \& Mauborgne's book (18), six fundamental approaches to reconstruct these market frontiers are described, which arise from the identification of systematic patterns used in the creation of blue oceans. These patterns, during their study, were grouped under the sixtrack scheme, which is based on the ability to see known realities with a new perspective. They are generally applicable to any sector of the industry.

The six paths resulting from analyzing and responding to these assumptions can be summarized as follows (Figure 2).

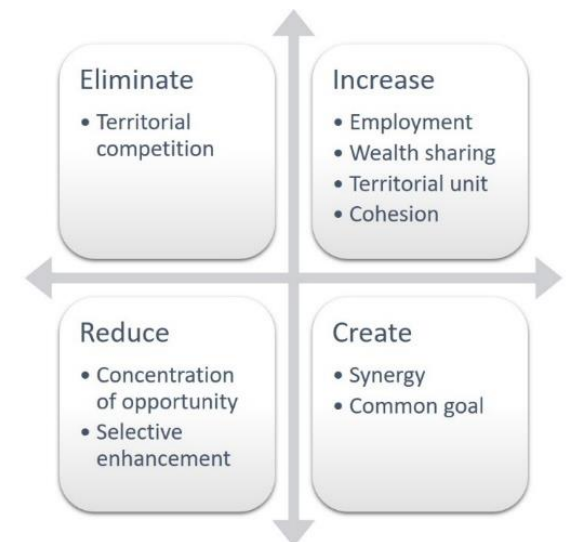

Figure 2. The six paths resulting from analyzing, Source: own production based on "The Blue Ocean Strategy" 


\subsubsection{Focusing on the global perspective rather than the numbers}

This second principle aims at aligning the strategic planning process to focus on the global perspective and apply the ideas to draw the strategic picture of the industry in such a way that it represents a blue ocean. It is an approach from which the risk of planning around a series of movements in the red ocean is reduced.

The use of a strategic framework, as this principle proposes, helps to focus the attention of the strategy on the global perspective rather than on figures and terminology, thus preventing getting caught up in operational details. It can be said to function as a wake-up call to recognize the need for change, helping to predict and chart the industry's future growth and profits.

\subsubsection{Going beyond existing demand}

The purpose of this third principle is to maximize the size of the blue ocean that is being created. Going beyond existing demand involves adding as much demand as possible to the new product or service, thus mitigating the risk of scale associated with the creation of a new market.

To achieve success with this approach, the common red ocean strategy of keeping existing customers and increasing business with them has to be abandoned. This fixation on existing customers, and the corresponding segmentation into increasingly thinner groups to better satisfy customer preferences, leads to intense competition and the creation of excessively narrow target markets.

However, to create blue oceans, the opposite path must be followed. The main objective is not to fixate on competition is a space within the market, which has not yet been exploited, and which can generate profitable growth, The difference between red oceans and blue oceans is that, while red oceans symbolize all existing areas of commerce, blue oceans represent business ideas that have not yet been explored. The industry must focus on non-customers and must take advantage of the things that all buyers value in common, thus consolidating the hitherto differentiated segments. This is how you get new customers who were previously not part of the market. The challenge of this principle is to correctly sense who the non-customers are in the industry and how to exploit their potential.

To facilitate their identification, three levels are created according to their relative distance from the market, with non-customers on the first level being the closest to the market, and those on the third level being the furthest away (Figure 3).

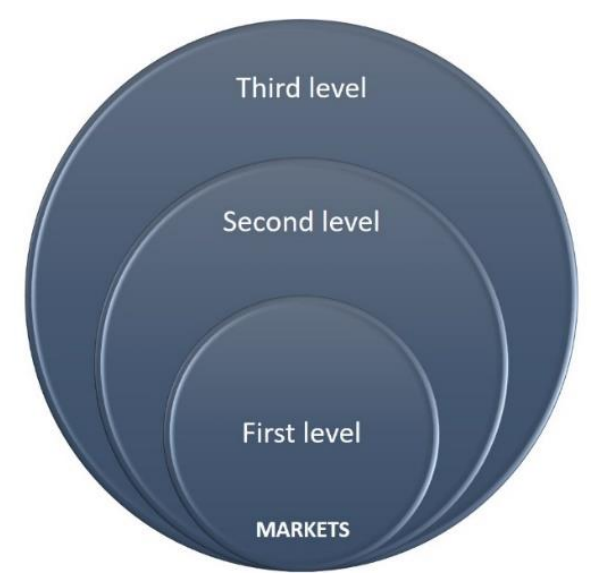

Figure 3. The three levels of non-customers. Source: own production based on "The Blue Ocean Strategy"

Finally, there are the non-third level customers, the group furthest from the market, and the customers of your industry. This group is made up of those non-customers who are unexplored because they consider that the business opportunities associated with them belong to other markets. Once the non-customers at each level have been identified, attention must be focused on those that represent the best business opportunities at that time. Also, it is necessary to explore if these three levels have common 
elements, which could trigger an even greater demand. Finally, the size of the new blue ocean must be harnessed to make the outcome sustainable and beneficial to all. This last issue will be explained in the next section.

\subsubsection{Applying the right strategic sequence}

The fourth principle of the Blue Ocean strategy is based on building a strong business model by managing and validating Blue Ocean ideas to ensure their commercial viability. The clarity in the sequence in which actions must be taken and their validation drastically reduces the risks of the new business model.

\subsection{Analysis of results and conclusions}

Once the blue ocean strategy applied to the port system has been developed, the results are analyzed, and conclusions are drawn.

\section{Results and discussion}

To determine the working scenario, the main technological tools of the 4.0 revolution and their possible application to seaports and other elements of the logistics chain were collected, obtaining data related to the Spanish system. The different aspects on which the technological comparison of Spanish ports will be made are logistics, mobility, environment, economy, social factor, and governance. For the research carried out, the fifth track of the Blue Ocean strategy was chosen, that is, exploring the functional or emotional attraction for buyers.

\subsection{Exploring the functional or emotional attraction for buyers}

The way industries compete can be of two types: based on their rational attractiveness, for which they rely on price and function, or the basis of their emotional attractiveness when they compete primarily based on feelings.
In these cases, to get out of the red oceans and discover unknown spaces, companies must question their functional or emotional orientation. They can do this by asking the following questions: Does your industry compete based on functional or emotional appeal? If your industry is competing based on emotional appeal, what are the elements that you will be able to remove to give it a functional twist? If you are competing because of functionality, what are the elements you can add to give it an emotional twist?

In answering the questions, the first one is clear: the Spanish port sector competes based on its functional attractiveness. This attractiveness, as discussed above, is reinforced by investments in the large commercial ports (such as the Port of Barcelona), which are those that can export an image of a powerful and efficient system abroad, and, as a consequence, the smaller ports lose relevance in the port system.

In view of the obvious discontent that exists in the smaller ports, to give the system an emotional turnaround, the concept of unity must be encouraged, that is to say, promoting clear, real, and joint participation of all its member ports (which means avoiding concentrating supply in certain points). This turn would also bring about more uniform economic growth in the national territory, a fairer distribution of wealth, and the promotion of employment.

The variables that will be used to define the current market trapped in a red ocean and the future blue ocean, and that therefore have the mission of making the emotional turn to the case study, are those proposed below:

- Territorial competition. Port competition extends beyond the port environment, as the benefits of a competent and profitable port are reflected in its immediate surroundings. This situation, which currently has a very 
high value, would become irrelevant in the blue ocean.

- The concentration of opportunities. Same as the variable of the second way. Each port struggles to postulate itself as the only possible solution to provide an adequate response to existing traffic. This occurs above all in the large ports and their international projection. The new market implies an opening to opportunities, that is, to their expansion, and not to their concentration.

- Selective promotion. For a concentration of opportunities to be perpetuated, there must first be a prior selection of ports to be promoted. The choice rests on issues such as their geographical position, the traffics they serve, their performance, or their profitability. The evolution proposed by this fifth way reduces the value of this variable to a minimum, although it does not eliminate it because it can be a resource in periods of testing or analysis of strategies.

- Employment. The new blue ocean, with its scheme of unity and distribution of opportunities, greatly increases the value of this variable, especially in the environments of the ports that are less commercially developed at present.

- Distribution of wealth. Strongly linked to the previous one, they are a consequence of each other. For this reason, the value is modified in the same way in the transition from the old to the new situation.

- Cohesion. The future market requires the cohesion of the territories that are part of the environment of the ports in question. This cohesion implies knowing the situation, the problems, and the potential of each of them to make a fair distribution of opportunities. It can be said that this is a variable that is closely linked to the concept of solidarity and, for this reason, confers added value to the new market.

- Collaboration. Achieving the desired cohesion, or the distribution of wealth or job creation necessary to make the system more sustainable requires first and foremost effective collaboration between ports. The emotional value of this variable is very high since it implies going beyond the establishment of commercial links or operational relations between ports, for which an overall vision is necessary, forgetting individuality. It is on this that new emotions are based, such as trust, and this is what sustains the innovative orientation of the set of variables proposed here.

- Synergy. Same case as the variable of the second way. Economic growth would be favored by the joint action of the different Spanish ports working as a unit. The eagerness to differentiate and concentrate traffic causes inequalities, which are visible in the different levels of debt or profit. The wealth obtained in the most profitable ports is shared with those in debt. If we act from the beginning with an efficient distribution of the traffics, the system could tend to balance itself.

- Common objective. It is a variable created for the new ocean and is a consequence of the unity of the system. It has a very high value, as it is the basis of the working scheme: the definition of a common objective prevents the measures taken by some ports from having undesirable consequences for others. To achieve this, processes such as information sharing, transparency, and standardization of procedures are fundamental. 
The variables that will be used to define the current market trapped in a red ocean and the future blue ocean, and that therefore have the mission of making the emotional turn to the case study, are those proposed below (Figure 4). Its corresponding value curve is shown in Figure 5.

\subsection{Future blue ocean}

Starting once again from the identification of colonists, and taking into account that to ensure a correct transition between the two scenarios these cannot disappear completely, but their value can be reduced, we can find those exposed here.

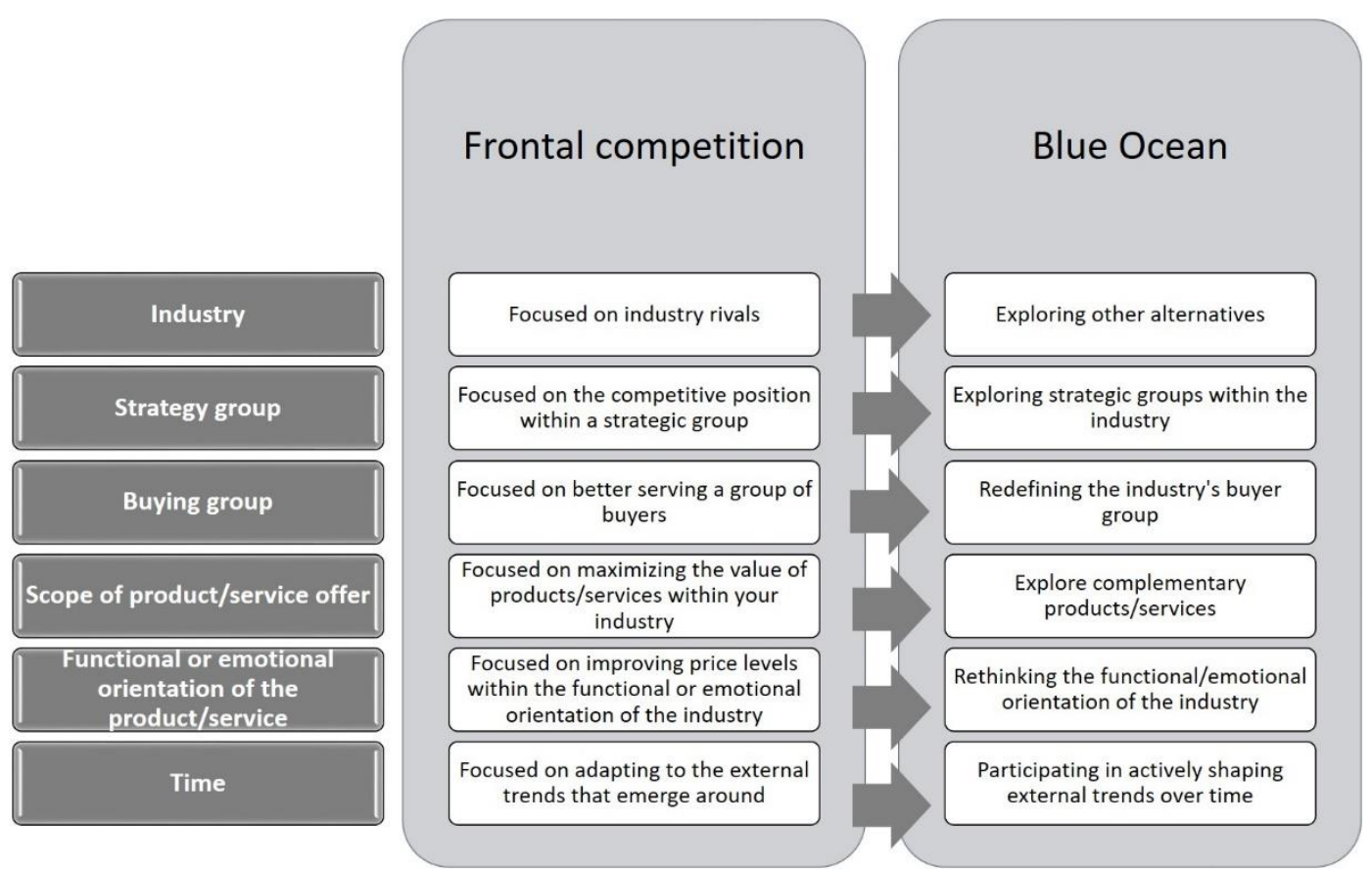

Figure 4. Matrix of the four actions. Fifth way: explore the functional or emotional appeal for buyers

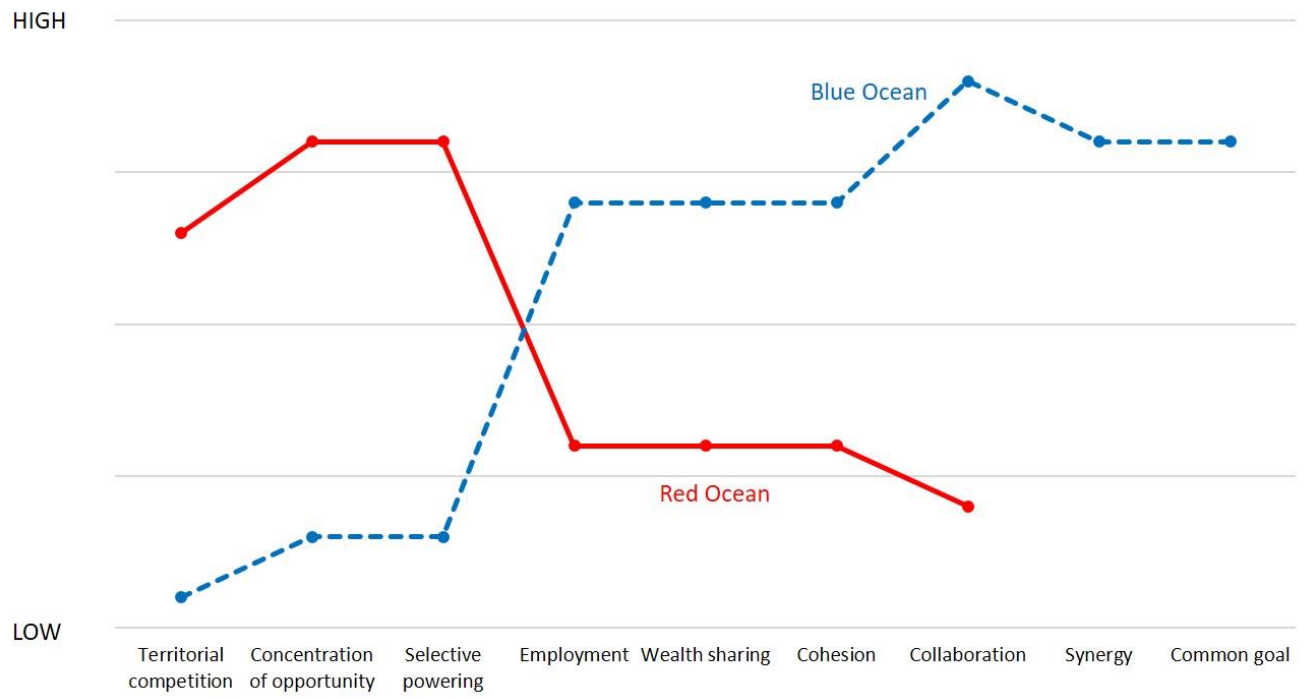

Figure 5. Value curve. Fifth way: explore the functional or emotional appeal for buyers 


\subsubsection{Investments (public and private)}

The reason for maintaining investments is the clear need that the industry has for them. In the new ocean, for example, it is necessary to invest in railway infrastructure (the current supply does not meet the demand). It should be noted that these investments could no longer be an instrument to promote competition, but as a tool to homogenize opportunities.

Finally, the pioneers that most differences between the two scenarios, offering unprecedented value and constituting the most powerful sources of growth are

- Dynamic rates.

- Digitized and synchromodal logistics chain.

- Overview.

In the case of dynamic rates, innovation would come from the hands of digitalization and new technologies supporting the concept, while value would come from the process of choosing prices, which would be impartial and transparent. Instead of each Port Authority setting the prices that best suit it to ensure its self-sufficiency and attract more traffic than its competitors, a centralized, digital, automatic system based on real-time decision-making would be responsible for performing this function according to the information provided by each port at any given time.

The digitized and synchromodal logistics chain brings innovation again through technology. The connection between modes and the choice of route and mode in real-time, in addition to providing information on the state of the infrastructure, means energy and time savings and optimization of processes. The value would be given by this optimization and by the provision of a service, both maritime and terrestrial, more flexible (its ability to adapt to the constraints of the environment in an instant). Within this transport logistics chain, the railway would already be fully integrated.

As for the overall vision, it refers to a new management model. This change of model implies innovation, while at the same time it represents a leap in value thanks to the promotion of collaboration between ports, transparency of processes and decision-making, and the exchange of information. The result of this map of pioneers, emigrants, and settlers is shown in Figure 6.

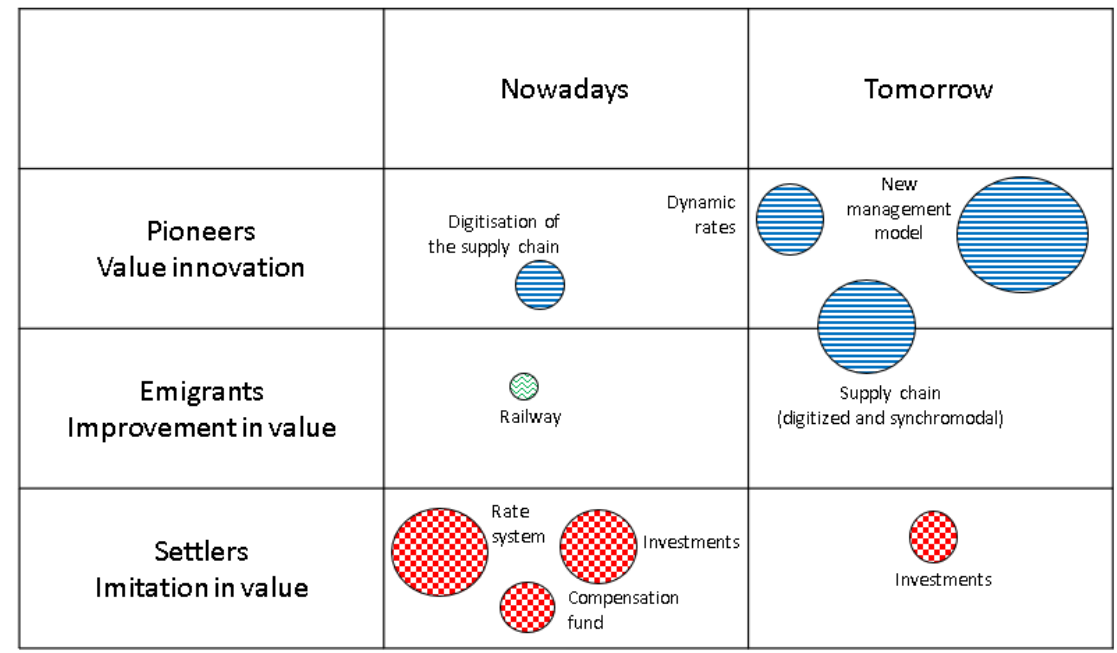

Figure 6. PEC map. A global perspective of the blue ocean for the Spanish port sector 


\subsection{Results of going beyond existing demand}

The way to cross the borders is by identifying non-customers in the industry, which are classified into three levels. The identification work is then carried out.

Starting with first-level non-customers, the following question can be used to help define them: What are the main reasons why first-level non-customers are willing to jump ship and leave their industry? This question needs to be approached from a unifying perspective, which in turn serves to consolidate the buyers' market, expanding it.

Its application to the case of the Spanish port sector could be through the identification, in the first place, of the clients, represented by those captive ship traffics from a select number of ports because they are the only ones capable of offering a service adequate to their needs. This could be the case of the large ports specialized in containerization. On the other hand, the non-first level clients, those buyers who use the system minimally, and think to abandon it as soon as they find something they consider better, would be those vessels that operate in the smaller ports (which consequently present a lower specialization index), but that as soon as they could do it in another type of ports, would leave to these.

Continuing with non-clients at the second level, these non-clients have no intention of entering the market because they consider it to be out of their reach or because it does not meet their expectations. An example of this level would be those traffics that prefer to operate in ports in other nearby countries (such as North Africa) because they consider the prices of the ports in these countries to be more competitive.

Finally, non-third level customers are those potential customers that have never been considered by the industry, the unexplored ones. In this respect, the ports of the system themselves can be identified in this role, more specifically the smaller ports. In order to reach this conclusion, it has been assumed that these ports must start to see themselves as recipients of products and services, that is, as recipients of opportunities to achieve balance in the system.

The solution proposed in this case is the creation of alliances between the ports of the system, i.e. their operation, and the dynamic fee system.

For non-clients of the first level, the fundamental aspect that makes them susceptible to leave the market is the lack of specialization of the smaller ports of the system. A fairer investment policy that avoids situations of overcapacity of port infrastructure in the ports that invest most in growth and diverts investment towards those ports in a clear situation of competitive disadvantage, would prevent the departure of these non-clients of the first level. At the same time, it would increase confidence in the sector. On the other hand, the already existing customers of the sector would not lose quality in the service they receive either (there is already an overcapacity of maritime infrastructures; not investing in them in the big ports does not mean a loss of capacity).

Non-customers at the second level would also benefit from this measure. The system of dynamic rates would favor the offer of prices more adjusted to the needs of each moment and could represent an instant solution to the capture of those traffics that operate in ports of nearby countries. Besides, the adoption of price values would be executed through software, capable of making decisions instantly according to the results of the analysis of the information provided to it. For this reason, they would be decisions aimed at achieving the balance of the system and taken transparently and impartially. 
Finally, as far as non-third level customers are concerned, the improvement of their strategic position in the national port sector and, consequently, in the international arena, would be achieved thanks to the two measures proposed. Both solutions represent the smaller ports an opportunity to increase their traffic and promote the local economy and territorial cohesion.

\subsection{Applying the right strategic sequence}

The purpose of this last principle of the strategy is to ensure the commercial viability of the proposed model. To achieve the objective, the steps indicated in the methodology must be followed, which consist of ensuring that the blue ocean works in the areas of buyer utility, price, cost, and adoption.

Considering the utility for the clients, the first step is to analyze through the levers proposed by the creators of the strategy, how the port sector can be activated to offer an exceptional utility to its clients. These levers are customer productivity (referring to the help the product or service provides to the customer to do things better or faster), simplicity, convenience, risk, image, and environment, and are applied to the buyer's experience cycle. For the analysis, the table shown in Table 1 is drawn up.

Table 1. The result of applying the right strategic sequence

\begin{tabular}{lcc}
\hline & Purchase & Use \\
\hline Productivity & $\mathrm{X}$ & $\mathbf{X}$ \\
Simplicity & $\mathrm{X}$ & $\mathbf{X}$ \\
Comfort & & $\mathbf{X}$ \\
Risk & $\mathrm{X}$ & \\
Image & $\mathrm{X}$ & \\
\hline Environment & $\mathbf{X}$ & $\mathbf{X}$ \\
\hline
\end{tabular}

The black blades represent those phases that thanks to the blue ocean experience an increase in utility in each area proposed by the six levers. In general, it can be seen how the new market offers improvements in all areas that buyers, both objectively and subjectively, analyze when choosing a service.

Productivity, on the other hand, improves at both levels of the buyer's experience cycle. In the first purchase phase, ships would not have to decide in which port to operate or establish commercial relations, thus reducing efforts, but the port system would take charge of that decision in real-time in a completely digital way, transmitting that decision to the ship. It could also be seen as helping the concept of synchromodality to make decisions on transport mode and route within the logistics chain, which would be made more efficient. Later, in the use phase, it is seen as this category is optimized by reducing waiting times. The dynamic system for the distribution of ships between the different ports that make up the Spanish port sector, by basing its operation on avoiding collapses and waiting times, has a positive impact on the operation of ships in the port system.

In terms of simplicity, both the standardization of procedures and the homogeneous digitalization of the ports, and the system of dynamic fees, contribute to minimizing the existing complexity in the current system. The purchase and use phases would again be the great beneficiaries.

The convenience, on the other hand, is understood as the possibility that buyers have to satisfy their needs 24 hours a day, 365 days a year would have its great improvement in the use phase. The application of the technology would reduce dependence on workers, whose availability and performance varies throughout the day. The help provided by the product or service to the consumer to do things better or 
faster will be supported by technology, therefore the dependence on traditional labor will be less, employees will have to perform other types of tasks being able to adjust the availability and increase yields.

As far as risk is concerned, it can be reduced on an economic, physical, or emotional level, including reputation. Thus, the blue ocean provides an exceptional utility in comparison to the red ocean thanks, above all, to transparency. This is evident in the purchase phase.

The image, related to the attitude of the port system when offering its services, also achieves its greatest usefulness in the purchase phase. The flexibility of the port sector to cope with variable demands and its capacity to adapt to circumstance gives ships an image of a solid yet dynamic system, capable of anticipating problems and avoiding them before they occur.

Finally, buyers would feel that their commitment to the environment is met thanks to the various systems for optimizing port operations, which would be fully digitized and monitored. In this way, times and fuel consumption would be much lower, resulting in greater utility in both phases.

\section{Conclusions}

The general conclusion reached by this research is that it is possible to apply market strategies to the Spanish port sector with a different methodology to that used so far. This means that to be able to face the future challenges of the system in the face of globalization and avoid stagnation, the state port system must look towards other strategic alternatives that help it to glimpse opportunities. Thus, the Blue Ocean strategy, considered ideal for this task due to its excellent results in other sectors of the economy, has put on the table a series of issues that Spanish ports must address to create a new market that is not based on competition.

\section{- Reconstruction of market borders}

As a result of the results obtained from the six routes, Spanish ports still have a long way to go in terms of sustainability, understood in its three dimensions: economic, social, and environmental.

In the economic dimension, the collaboration between ports is the most valuable variable. This is because only with collaboration can there be a true and transparent flow of information that allows the establishment of a common objective that satisfies the motivations of all the ports in the Spanish system.

From the social dimension, on the other hand, it can be concluded that the variable with the highest value is territorial cohesion. The future market requires the cohesion of the territories that are part of the environment of the ports in question. This cohesion implies knowing the situation, the problems, and the potential of each of them to make a fair distribution of opportunities. It can be said that this is a variable that is closely linked to the concept of solidarity and, for this reason, confers added value on the new market. Achieving the desired cohesion, or the distribution of wealth or job creation necessary to make the system more sustainable requires first and foremost effective collaboration between ports. The emotional value of this variable is very high since it implies going beyond the establishment of commercial links or operational relations between ports, for which an overall vision is necessary, forgetting individuality. It is here that new emotions, such as trust, are based, and it is here that the innovative orientation of the set of variables proposed here is sustained. The current competition market accentuates territorial differences and will continue to do so if its rules are not changed. For this reason, it is almost obligatory to implement initiatives that transform the sector's rational thinking and bring it to a 
more emotional level. In this sense, the Blue Ocean Strategy has fulfilled its purpose.

Finally, from the environmental dimension, it can be said that the variable whose value is highest is synchro-modality. It is only through its operation thanks to the implementation of rail for the transport of goods to and from ports, and of digital processes, that dependence on the road can be reduced. Once again, the Blue Ocean has managed to highlight the weaknesses of the hitherto well-known port sector and to propose innovative solutions with a high value for all the actors involved.

\section{- Focusing on the global perspective rather than the figures}

The implementation of the second principle of the strategy has concluded that most of the measures proposed for the promotion of a new ocean are value innovation measures, thus avoiding the mistake made so far from imitating value. Its graphic representation also makes it possible to illustrate this phenomenon hastily.

\section{- Going beyond the existing demand}

The search for non-customers in the industry proposed by the third principle of the strategy has resulted in an expansion of the agents identified so far as market demand. Thus, the blue ocean is fulfilling its promise of increased demand.

\section{- Applying the right strategic sequence}

This fourth principle of the blue ocean has made it possible to glimpse those aspects that may be a barrier to the development of the proposed measures, and their corresponding solutions.

\section{Funding Statement}

The author(s) received no specific funding for this work.

\section{References}

(1) Panayides PM. Global supply chain integration and competitiveness of port terminals. In: Wang J, Olivier D, Notteboom T, Slack B, editors. Ports, Cities, and Global Supply Chains. 1st ed. Aldershot: Ashgate Publishing Company; 2007. p. 43-56.

(2) Zereik E, Bibuli M, Miskovic N. Challenges and future trends in marine robotics. Annu Rev Control. 2018;46:350-68. https://doi.org/10.1016/j.arcontrol.2018.1 0.002 .

(3) Heilig L, Lalla-Ruiz E, Voß S. Digital transformation in maritime ports: analysis and a game-theoretic framework. NETNOMICS Econ Res Electron Netw. 2017;18:227-254.

https://doi.org/10.1007/s11066-017-9122$\mathrm{x}$.

(4) Heilig L, Voß S, Schwarze S. An analysis of digital transformation in the history and future of modern ports. In: Proceedings of the 50th Hawaii international conference on system sciences (HICSS). Piscataway: IEEE Institute of Electrical and Electronics Engineers; 2017. p. 1341-1350.

Acciaro M, Renken K, Khadiri N El. Technological Change and Logistics Development in European Ports. In: European Port Cities in Transition. Springer, Cham; 2020. p. 73-88. 
(6) González-Cancelas N, Serrano BM, Soler-Flores F. Seaport Sustainable: Use of Artificial Intelligence to Evaluate Liquid Natural Gas Utilization in Short Sea Shipping. Transp J. 2019;58(3):197221.https://doi.org/10.5325/transportation j.58.3.0197.

(7) Martín AES, González-Cancelas N, Serrano BM, Soler-Flores F. Towards the sustainability of the Spanish Port System through the Business Observation Tool. Proc Inst Civ Eng - Marit Eng. 2020. https://doi.org/10.1680/jmaen.2020.25.

[epub ahead of print].

(8) Castelein B, Geerlings H, Duin R Van. The reefer container market and academic research: A review study. J Clean Prod. 2020;256:120654.https://doi.org/10.1016/ j.jclepro.2020.120654.

(9) González-Cancelas N, Serrano BM, Infantes ME, Soler-Flores F, CamareroOrive A. Escenario de digitalización para el sistema portuario español. Rev Transp y Territ. 2020;(22). https://doi.org/10.34096/rtt.i22.6377.

(10) Dooms M, Lugt L Van Der, Parola F, Satta G, Song D-W. The internationalization of port managing bodies in concept and practice. Marit Policy Manag. 2019;46(5):585-612. https://doi.org/10.1080/03088839.2019.1 584340 .

(11) Serrano BM, González-Cancelas N, Soler-Flores F. Modelo de inteligencia artificial para el análisis de la gestión de la sostenibilidad en puertos marítimos. DYNA Ing e Ind. 2018;93(1):67-74. https://doi.org/10.6036/8508.
(12) Garcia-Alonso L, Monios J, Vallejo-Pinto JÁ. Port competition through hinterland accessibility: the case of Spain. Marit Econ Logist. 2019;21:258277.https://doi.org/10.1057/s41278-0170085-5.

(13) Serrano BM, González-Cancelas N, Soler-Flores F. Sustainable short sea shipping: social component analysis through decision networks. Proc Inst Civ Eng - Marit Eng. 2018;171(4):135-44. https://doi.org/10.1680/jmaen.2017.19.

(14) González AR, González-Cancelas N, Serrano BM, Orive AC. Preparation of a Smart Port Indicator and Calculation of a Ranking for the Spanish Port System. Logistics. 2020;4(2):9. https://doi.org/10.3390/logistics4020009.

(15) Zhang X, Roe M. Port Competition. In: Maritime Container Port Security. 2019.

(16) Tavasszy L, Behdani B, Konings R. Intermodality and Synchromodality. In: Geerlings H, Kuipers B, Zuidwijk R, editors. Ports and Networks Strategies, Operations and Perspectives. 2017. p. 251-66.

(17) Douaioui K, Fri M, Mabrouki C, Semma EA. Smart port: Design and perspectives. In: 2018 4th International Conference on Logistics Operations Management (GOL). Le Havre, France: IEEE; 2018. p. $1-6$.

(18) Mauborgne RA, Kim WC. La estrategia del océano azul. Harvard Deusto Bus Rev. 2005;(131):22-31. 